\title{
Petrogenesis and geochronology of the Arkasani Granophyre and felsic Dalma volcanic rocks: implications for the evolution of the Proterozoic North Singhbhum Mobile Belt, east India
}

\author{
H.N.BHATTACHARYA ${ }^{a}, \mathrm{D}$. R. N E L S O N ${ }^{a}, E \cdot R$. THE R N \& \\ W. ALTERMANN \\ ${ }^{a}$ Department of Geology, Presidency University, 86/1 College Street, Kolkata 700 073, India \\ ${ }^{b}$ Department of Applied Physics, Curtin University of Technology, GPO Box U1987, Perth 6001, Australia \\ 'Department of Geology, Kumba-Exxaro Chair in Geodynamics, University of Pretoria, Pretoria, South Africa
}

\begin{abstract}
The North Singhbhum Mobile Belt (NSMB) is a $200 \mathrm{~km}$ long, curved Proterozoic foldthrust belt that skirts the northern margin of the Archean Singhbhum Craton of NE India. The Singhbhum Shear Zone (SSZ) developed between the Dhanjori and Chaibasa formations near the southern margin of the NSMB and represents an important Cu-U-P metallotect. A SHRIMP U-Pb zircon date of $1861 \pm 6 \mathrm{Ma}$, obtained for the syn- to post-kinematic Arkasani Granophyre that has intruded the SSZ, provides a minimum age for the prolonged tectonic activity and mineralization along the SSZ and for the time of closure of the Chaibasa and Dhanjori sub-basins. The Dalma Volcanic Belt, a submarine rift-related bimodal mafic-felsic volcanic suite, forms the spine of the NSMB. A SHRIMP U-Pb zircon igneous crystallization date of $1631 \pm 6 \mathrm{Ma}$ was obtained for an unfoliated felsic volcanic rock from the base of the Dalma volcanic sequence. These new findings suggest that the different sub-basins in the NSMB evolved diachronously under contrasting tectonic environments and were juxtaposed during a later orogenic movement.
\end{abstract}

Keywords: Arkasani Granophyre, Dalma volcanism, North Singhbhum Mobile Belt, Singbhum Shear Zone.

\section{Introduction}

The eastern segment of the Indian Precambrian Shield, commonly referred to as the Singhbhum Protocontinent, preserves a record of geological events spanning early Archaean - late Proterozoic time (Saha, 1994; Sarkar \& Gupta, 2012). The early Archaean Singhbhum Craton (Sarkar \& Saha, 1983) comprises tonalite-trondhjemite-granodiorite and middle-late Archaean supracrustal volcano-sedimentary greenstone belt successions (IOG) that have been intruded by late Archaean granites. A Proterozoic thrust-fold belt, the North Singhbhum Mobile Belt (cf. Gupta, Basu \& Ghosh, 1980; Mukhopadhyay, 1984; Sarkar, Gupta \& Basu, 1992; Fig. 1), occurs between the Archean Singhbhum Craton in the south and the Chhotanagpur Granite Gneissic Complex in the north. The North Singhbhum Mobile Belt (NSMB) is a nearly $200 \mathrm{~km}$ long and $50 \mathrm{~km}$ wide curvilinear orogenic belt (Fig. 1). In the east, the belt has a general north-south trend, which gradually changes to east-west in the central part and NE-SW in the west (Fig. 1). The NSMB is regarded as a Proterozoic rift basin (Bhattacharya \& Mahapatra, 2008) that developed along a major suture zone (Sarkar \& Saha, 1983). Rifting produced Dhanjori, Chaibasa, Dalma and North Dalma sub-basins with distinctly different petrotectonic evolutionary histories, juxtaposed as linear domains during a terminal orogeny (Muk-

^Author for correspondence: hbaruamu@gmail.com hopadhyay, 1984; Sarkar, Gupta \& Basu, 1992). The contacts between such linear domains are sheared with north-dipping shear planes. A simplified stratigraphy of the terrane is provided in Table 1.

The southern margin of the NSMB is marked by a curved zone of intense shearing, $1-10 \mathrm{~km}$ wide and over $200 \mathrm{~km}$ long, known as the Singhbhum Shear Zone (SSZ) (Fig. 1) which separates the Chaibasa Formation of the Singhbhum Group and the Dhanjori Group (Saha, 1994). The SSZ becomes bifurcated in the west, with the Chakradharpur Granite (CKPG) coming in between the two branches (Fig. 1). The shear planes in the shear zone dip at $45^{\circ}$ or less towards the north. Several granite lenses were emplaced along the shear zone (Dunn \& Dey, 1942). The shear zone was active during a prolonged period and is characterized by repeated cycles of mylonitization, folding and down-dip rotation/stretching of pre-existing structures, indicating ductile shearing (Sengupta \& Ghose, 1997). Truncation of stratigraphic units in the zone lying between Kudada and Saraikela indicates thrusting along the Singhbhum Shear Zone (Bhattacharya \& Mahapatra, 2008). Metamorphism close to the shear zone further suggests crustal thickening due to thrusting (Mahato et al. 2008). The SSZ therefore records both ductile shearing and thrusting during the closure of the Dhanjori and Chaibasa sub-basins.

Five different tectonic models have been proposed to explain the evolution of the NSMB. Three of these models are based on principles of plate tectonic (Sarkar \& 
Table 1. Generalized stratigraphy of Singhbhum, east India.

\begin{tabular}{|c|c|c|}
\hline $1.6-0.7 \mathrm{Ga}$ & Younger granitoids & \multirow{3}{*}{ Dhanjori Group. Singhbhum Group, Dalma volcanic rocks and Kolhan Group } \\
\hline \multirow{3}{*}{$3.1 \mathrm{Ga}$} & Proterozoic fold-belts and supracrustals & \\
\hline & Singhbhum Granite-B & \\
\hline & Iron Ore Group & $\begin{array}{l}\text { Ultramafic to felsic volcanic rocks, conglomerate, quartzites, phyllites, } \\
\text { dolomite, tuffs and banded iron formation }\end{array}$ \\
\hline $3.3 \mathrm{Ga}$ & Singhbhum Granite-A & \\
\hline $3.4 \mathrm{Ga}$ & Older Metamorphic Tonalitic Gneiss & Foliated granitoids \\
\hline$>3.4 \mathrm{Ga}$ & Older Metamorphic Group & Quartzites, mica schists, calc-silicates and amphibolites \\
\hline & & Basement not identified \\
\hline
\end{tabular}

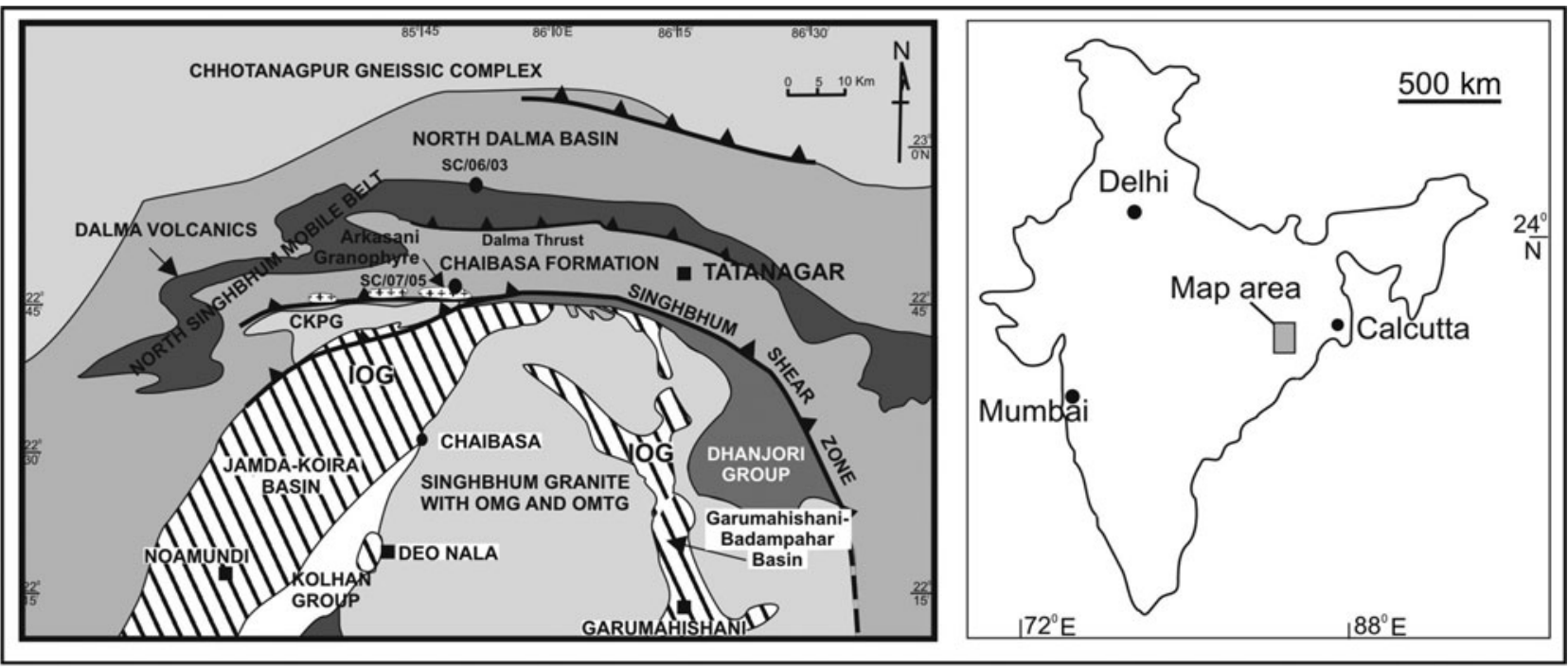

Figure 1. Geological map of North Singhbhum Mobile Belt (NSMB), showing the occurrences of Arkasani Granophyre, Dalma volcanic rocks and Singhbhum Shear Zone. Sample locations for geochronological analyses and other important stratigraphic units are also shown in the map. The location of the study area is shown in the map of India.

Saha, 1977; Bose \& Chakraborti, 1981; Sarkar, 1982; Bose, Chakrabarti \& Saunders, 1989), drawing analogues from Phanerozoic crustal segments. The fourth model proposes intracratonic extension and ensialic orogenesis with or without reference to an early stage of a Wilson Cycle (Gupta, Basu \& Ghosh, 1980; Mukhopadhyay, 1984; Sarkar, Gupta \& Basu, 1992; Gupta \& Basu, 2000; Sarkar, 2000). The fifth model (Bhattacharya \& Mahapatra, 2008) emphasizes sedimentolo-gical aspects of the sub-basins and proposes the form-ation of younger basins along the margins of the main rift and their collapse during a terminal orogeny. As a result of this south-directed terminal orogenic move-ment, the Chhotonagpur Granite Gneissic Complex in the north overrode the NSMB along a thrust, and the NSMB was driven onto the Archean cratonic block lying to the south.

The Dhanjori and Chaibasa sub-basins of the NSMB may have developed during reactivation of regional curved faults that were formed during doming of the Archean craton as a result of the emplacement of granite sheets (Roy \& Bhattacharya, 2012).

The findings of the present study indicate that the NSMB does not form a single regional rift basin, as was conceived in proposed models, but instead consists of separate basins that developed over a considerable time period. The present paper integrates a stratigraphic, sedimentologic, structural and tectonic database with precise SHRIMP U-Pb zircon dates to present a new and comprehensive model for the evolution of the NSMB.

\section{Arkasani Granophyre}

At least seven isolated lens-shaped granitic bodies, known as the Arkasani Granophyre, were emplaced well within the mylonitized metasediments of the NSMB, forming the northern branch of the forked Singhbhum Shear Zone in the north of CKPG-Gneissic Complex (Fig. 1). The largest body forms the Arkasani Hill. These granitic bodies were first mapped by Dunn (1929) and later studied by Banerjee, Bhattacharya \& Chattaopadhyay (1978), Sengupta et al. (1984) and Chattopadhyay (1990). The cores of these granite bodies are generally massive and porphyritic (Fig. 2a), but they are schistose near their peripheries (Fig. 2b). Schistosity is more pervasive in the smaller bodies. Near their margins, these granitic bodies commonly contain enclaves of mica-schist and schistose amphibolites. Sengupta et al. (1984) reported a $\mathrm{Rb}-\mathrm{Sr}$ whole-rock isochron date of $1.0 \mathrm{Ga}$, interpreted as the time of a post-emplacement thermal event, for the Arkasani Granophyre. 

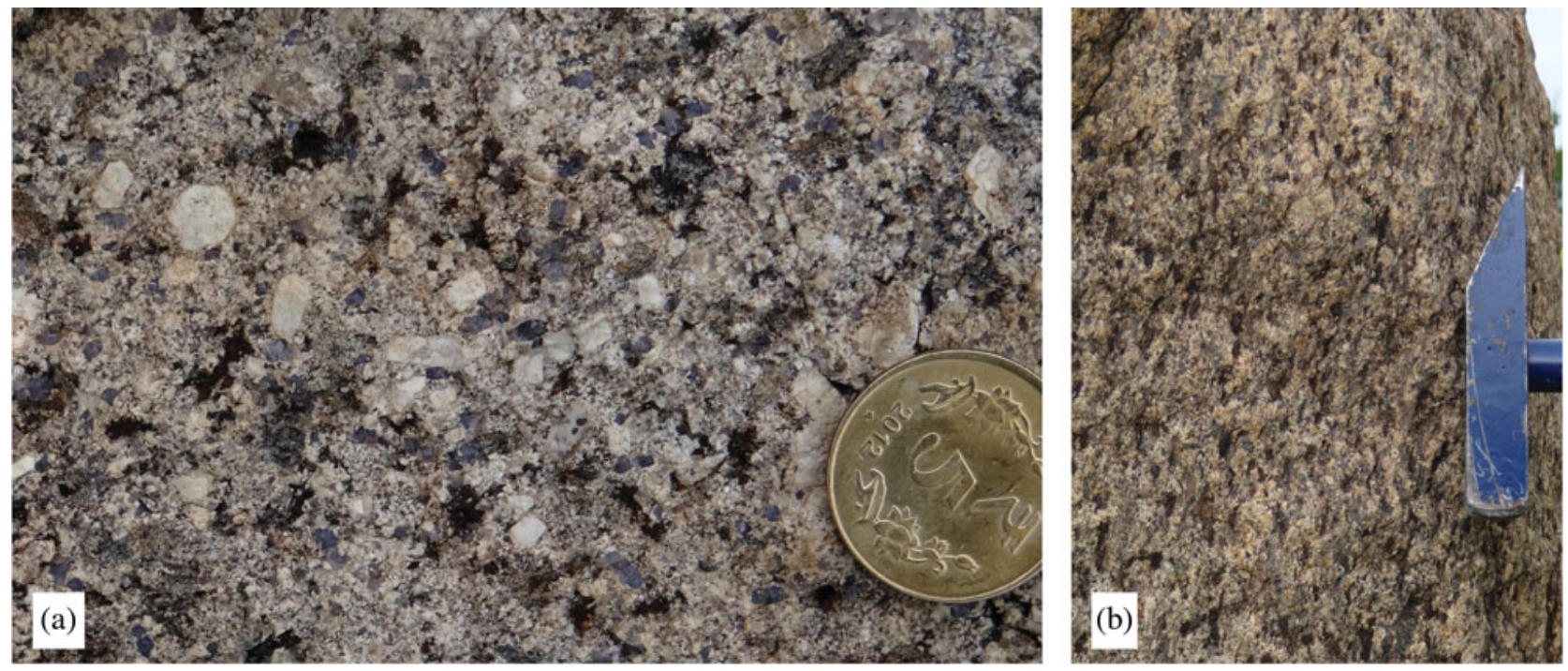

Figure 2. (Colour online) Field photographs of (a) porphyritic variety and (b) schistose variety of Arkasani Granophyre. Schistosity is defined by biotite/muscovite flakes and flattened and recrystallized quartz grains forming quartz ribbons $(\mathrm{QR})$.

The Arkasani Granophyre is a medium- to coarsegrained porphyritic rock with phenocrysts of plagioclase $\left(\mathrm{An}_{22}-\mathrm{An}_{35}\right)$ commonly occurring as clusters or cumulates. The groundmass contains sodic plagioclase $\left(\mathrm{An}_{2}-\mathrm{An}_{15}\right)$, K-feldspar, greyish quartz, biotite and muscovite as the major minerals, with accessory tourmaline, epidote, zircon, apatite, titanite and magnetite. The grain size is commonly reduced towards the body margins. The groundmass shows intergrowth texture, mostly granophyric with myrmekitic and micropegmatitic variations. The proportion of granophyric intergrowth in these granite bodies commonly increases towards their margins. Along the margins the granite bodies are schistose, with the schistosity defined by flattened and recrystallized quartz grains with wavy extinction forming quartz ribbons, and parallel-aligned biotite and muscovite flakes (Fig. 2b).

Major, trace and rare Earth element (REE) chemical compositions of the Arkasani Granophyre, obtained at the Wadia Institute of Himalayan Geology by inductively coupled plasma mass spectrometry (ICPMS; Khanna et al. 2009), are presented in Table2. Bulk chemical compositions of granitic rocks that have intruded the Older Metamorphic Group at Champua, Garumahisani Granite and Mayurbhanj Granite are also listed in Table 2 for comparison. The $\mathrm{SiO}_{2}$ content of the Arkasani Granophyre lies within the range 71.79-73.36 wt \%, $\mathrm{K}_{2} \mathrm{O}$ exceeds $\mathrm{Na}_{2} \mathrm{O}$ and the $\mathrm{Ba}$ and $\mathrm{U}$ contents are exceptionally high. Plots in the $\mathrm{SiO}_{2} \mathrm{v}$. $\mathrm{Na}_{2} \mathrm{O}+\mathrm{K}_{2} \mathrm{O}$ classification diagram (after Cox, Bell \& Pankhurst, 1979) show the granitic character of the Arkasani Granophyre (Fig. 3a), whereas plots in the A/ NK (molecular proportion of $\mathrm{Al}_{2} \mathrm{O}_{3} / \mathrm{Na}_{2} \mathrm{O}+\mathrm{K}_{2} \mathrm{O}$ ) v. $\mathrm{A} / \mathrm{CNK}$ (molecular proportion of $\mathrm{Al}_{2} \mathrm{O}_{3} / \mathrm{CaO}+\mathrm{Na}_{2} \mathrm{O}$ $+\mathrm{K}_{2} \mathrm{O}$ ) diagram (after Maniar \& Piccoli, 1989) reveal its metaluminous character (Fig. 3b). Plots of chondrite-normalized trace elements show prominent negative $\mathrm{Sr}, \mathrm{P}, \mathrm{Ti}$ and $\mathrm{V}$ anomalies (Fig. 4a).
Chondrite-normalized REE plots (Fig. 4b) show an unfraction-ated pattern $\left([\mathrm{La} / \mathrm{Yb}]_{\mathrm{uc}}=2.04-2.42\right)$ with slight en-richment in the light REEs (LREEs) relative to heavy REEs (HREEs), and a prominent negative $\mathrm{Eu}$ anomaly $\left(\mathrm{Eu} / \mathrm{Eu}^{*}=0.59-0.67\right)$.

The porphyritic texture of the Arkasani Granophyre reflects early growth of feldspar crystals during slight cooling of the magma, followed by finer grains resulting from more rapid cooling due to shallow emplacement. The granophyric texture indicates rapid and simultaneous crystallization of quartz and K-feldspar from an under-cooled magma at shallow depth (Clarke, 1992). Flattened quartz grains with wavy extinction and parallel-aligned biotite and muscovite flakes defining schistosity are likely responses to synto post-kinematic emplacement (see also Sarkar \& Gupta, 2012). Apatite, zircon and magnetite grains are euhed-ral, consistent with their primary nature (Clarke, 1992). These minerals form the majority of inclusions in other minerals.

The relatively constant $\mathrm{K}_{2} \mathrm{O} / \mathrm{Na}_{2} \mathrm{O}$ and $\mathrm{K}_{2} \mathrm{O}>\mathrm{Na}_{2} \mathrm{O}$ of the Arkasani Granophyre indicate differentiation of magma generated from a single source (Jung et al. 1999), whereas Ti/P ratios near 2 and the negative $\mathrm{Nb}$ anomaly suggest a shallow crustal source. $\mathrm{Rb} / \mathrm{Sr}$ (2.48-2.61) and low $\mathrm{Sr} / \mathrm{Ba}(0.05-0.07)$ ratios are the result of early crystallization of plagioclase from the melt dur-ing fractional crystallization. The negative $\mathrm{Sr}$ and Eu anomalies (Fig. 4a, b) are consistent with early plagio-clase fractionation (Rollinson, 1993). Prominent $\mathrm{Zr}_{2}, \mathrm{P}_{2} \mathrm{O}_{5}, \mathrm{~T}$ i $\mathrm{O}$ and $\mathrm{V}$ anomalies possibly reflect crystal-lization/removal of accessory minerals such as rutile, apatite, zircon and magnetite from the melt.

High $\mathrm{K}$ contents, low Ti/P ratios, the negative $\mathrm{Nb}$ anomaly and unfractionated HREE (and Y) lend strong support in favour of the melting of a metaluminous shallow crustal source for the generation of Arkasani Granophyre (see also Sengupta et al. 1984). Rb 
Table 2. Major element, trace and rare Earth element composition of Arkasani Granophyre and other granites of the Singhbhum region.

\begin{tabular}{|c|c|c|c|c|c|c|c|c|c|}
\hline & A1 & $\mathrm{A} 2$ & A3 & D1 & D2 & D3 & CSG & GG & MG \\
\hline \multicolumn{10}{|l|}{ Major element (wt \%) } \\
\hline $\mathrm{SiO}_{2}$ & 73.36 & 72.55 & 71.79 & 74.89 & 74.81 & 75.36 & 73.01 & 71.56 & 77.18 \\
\hline $\mathrm{TiO}_{2}$ & 0.30 & 0.30 & 0.31 & 0.27 & 0.3 & 0.26 & 0.10 & 0.21 & 0.30 \\
\hline $\mathrm{Al}_{2} \mathrm{O}_{3}$ & 13.52 & 13.11 & 13.03 & 12.20 & 12.34 & 11.9 & 13.90 & 14.58 & 11.21 \\
\hline $\mathrm{Fe}_{2} \mathrm{O}_{3}$ & 3.56 & 3.49 & 3.56 & 3.06 & 3.29 & 3.04 & 0.94 & 2.21 & 3.88 \\
\hline $\mathrm{MnO}$ & 0.01 & 0.01 & 0.01 & 0.06 & 0.06 & 0.06 & 0.01 & 0.04 & 0.05 \\
\hline $\mathrm{MgO}$ & 0.37 & 0.33 & 0.39 & 0.34 & 0.34 & 0.37 & 0.11 & 0.41 & 0.07 \\
\hline $\mathrm{CaO}$ & 0.93 & 0.85 & 0.98 & 0.40 & 0.37 & 0.4 & 1.04 & 1.83 & 0.80 \\
\hline $\mathrm{Na}_{2} \mathrm{O}$ & 2.99 & 2.74 & 3.13 & 3.78 & 3.70 & 3.79 & 3.92 & 4.91 & 3.54 \\
\hline $\mathrm{K}_{2} \mathrm{O}$ & 4.42 & 4.27 & 4.36 & 3.96 & 3.87 & 3.8 & 5.01 & 3.23 & 3.89 \\
\hline $\mathrm{P}_{2} \mathrm{O}_{5}$ & 0.15 & 0.14 & 0.15 & 0.6 & 0.6 & 0.7 & 0.03 & 0.08 & 0.03 \\
\hline SUM & 99.61 & 97.80 & 97.71 & 99.56 & 99.98 & 100.18 & 98.07 & 99.06 & 100.95 \\
\hline Loss on ignition (LOI) & 1.08 & 1.11 & 1.08 & 0.52 & 0.3 & 0.5 & 0.67 & 0.89 & 0.64 \\
\hline $\mathrm{Na}_{2} \mathrm{O} / \mathrm{K}_{2} \mathrm{O}$ & 0.68 & 0.64 & 0.72 & 0.95 & 0.96 & 1.00 & 0.78 & 1.52 & 0.91 \\
\hline \multicolumn{10}{|l|}{ Trace element (ppm) } \\
\hline $\mathrm{Ba}$ & 1100 & 1028 & 1175 & 1158 & 1154 & 1270 & 307 & 388 & 1823 \\
\hline $\mathrm{Cr}$ & 28 & 25 & 29 & 14 & 14 & 16 & 8 & 12 & 19 \\
\hline $\mathrm{V}$ & 9 & 10 & 10 & 9 & 9 & 8 & 6 & 27 & $<5.0$ \\
\hline $\mathrm{Co}$ & 150 & 135 & 145 & 62 & 58 & 67 & 104 & 129 & 78 \\
\hline $\mathrm{Ni}$ & 17 & 15 & 18 & 4 & 4 & 3 & $<5.0$ & $<5.0$ & $<5.0$ \\
\hline $\mathrm{Cu}$ & 23 & 21 & 24 & 18 & 17 & 20 & 3 & 10 & 8 \\
\hline $\mathrm{Zn}$ & 14 & 15 & 12 & 34 & 36 & 31 & 18 & 41 & 97 \\
\hline $\mathrm{Ga}$ & 15 & 16 & 14 & 15 & 15 & 13 & 18 & 19 & 19 \\
\hline $\mathrm{Pb}$ & 9 & 10 & 8 & 26 & 24 & 27 & 26 & 18 & 22 \\
\hline Th & 28 & 29 & 26 & 32 & 35 & 32 & 5 & 9 & 10 \\
\hline $\mathrm{Rb}$ & 169 & 180 & 165 & 114 & 105 & 113 & 124 & 94 & 73 \\
\hline $\mathrm{U}$ & 5.5 & 5.5 & 6 & 6.5 & 6.8 & 5.9 & $<5.0$ & $<5.0$ & $<5.0$ \\
\hline $\mathrm{Sr}$ & 68 & 72 & 63 & 40 & 43 & 39 & 244 & 365 & 82 \\
\hline $\mathrm{Y}$ & 33 & 36 & 32 & 35 & 32 & 37 & 17 & 15 & 21 \\
\hline $\mathrm{Zr}$ & 259 & 240 & 284 & 254 & 233 & 264 & 101 & 139 & 300 \\
\hline $\mathrm{Nb}$ & 20 & 21 & 20 & 17 & 19 & 17 & 6 & 8 & 20 \\
\hline $\mathrm{Sc}$ & 14.8 & 14 & 13.6 & 13.2 & 13.6 & 12.9 & 0.1 & 1.8 & 0.8 \\
\hline $\mathrm{Rb} / \mathrm{Sr}$ & 2.49 & 2.50 & 2.62 & 2.85 & 2.44 & 2.90 & 0.51 & 0.26 & 0.89 \\
\hline $\mathrm{Sr} / \mathrm{Ba}$ & 0.06 & 0.07 & 0.05 & 0.03 & 0.04 & 0.03 & 0.79 & 0.94 & 0.04 \\
\hline \multicolumn{10}{|c|}{$\overline{\text { Rare Earth element (ppm) }}$} \\
\hline $\mathrm{La}$ & 87 & 80 & 95 & 66 & 61 & 71 & 17 & 36 & 63 \\
\hline $\mathrm{Ce}$ & 168 & 170 & 187 & 124 & 130 & 120 & 28 & 58 & 157 \\
\hline $\operatorname{Pr}$ & 18 & 16 & 18 & 12.8 & 12.6 & 11.9 & 2.5 & 5.8 & 11.8 \\
\hline $\mathrm{Nd}$ & 74.6 & 82.7 & 72.7 & 53 & 51.6 & 54.2 & 9.3 & 21.1 & 49 \\
\hline $\mathrm{Sm}$ & 15.8 & 16.5 & 15.6 & 12 & 11.6 & 13.2 & 1.8 & 3.5 & 9.5 \\
\hline $\mathrm{Eu}$ & 1.45 & 1.33 & 1.5 & 1.6 & 1.64 & 1.72 & 0.77 & 0.77 & 2.62 \\
\hline Gd & 12.6 & 11.6 & 12.3 & 10.9 & 9.8 & 10.9 & 1.4 & 2.8 & 8.5 \\
\hline $\mathrm{Tb}$ & 2.01 & 1.91 & 2.02 & 1.92 & 1.76 & 1.93 & 0.19 & 0.34 & 1.32 \\
\hline Dy & 11 & 10.5 & 11.5 & 11.9 & 10.9 & 12.3 & 0.9 & 1.5 & 7.4 \\
\hline Ho & 2.34 & 2.69 & 2.4 & 2.82 & 2.65 & 2.88 & 0.17 & 0.3 & 1.64 \\
\hline $\mathrm{Er}$ & 6.1 & 5.1 & 5.4 & 7.3 & 7.5 & 7.3 & 0.4 & 0.8 & 4.3 \\
\hline $\mathrm{Tm}$ & 0.8 & 0.8 & 0.7 & 1.01 & 0.99 & 1.02 & 0.05 & 0.09 & 0.58 \\
\hline $\mathrm{Yb}$ & 5.1 & 5.4 & 5.4 & 6.4 & 6.27 & 6.72 & 0.3 & 0.6 & 4 \\
\hline $\mathrm{Lu}$ & 0.74 & 0.81 & 0.78 & 0.96 & 0.9 & 0.97 & 0.05 & 0.09 & 0.64 \\
\hline $\mathrm{Eu} / \mathrm{Eu}^{*}$ & 0.63 & 0.59 & 0.66 & 0.43 & 0.47 & 0.44 & 2.96 & 1.50 & 1.78 \\
\hline
\end{tabular}

A1-A3 - Arkasani Granophyre; D1-D3 - Dalma felsic volcanic rocks; CSG - Champua syn-tectonic granite; GG - Garumahisani granite; MG - Mayurbhanj granite.

v. $\mathrm{Y}+\mathrm{Nb}$ plots (Fig. 5a) after Pearce, Harris \& Tindale (1984) show that the Arkasani Granophyre has some geochemical similarities to recent volcanic arc granites with proximity to within-plate granite. The $\mathrm{R}_{1}(4 \mathrm{Si}-$ $11(\mathrm{Na}+\mathrm{K})-2(\mathrm{Fe}+\mathrm{Ti})$ v. $\mathrm{R}_{2}(6 \mathrm{Ca}+2 \mathrm{Mg}+\mathrm{Al}) \mathrm{dia}-$ gram (Fig. 5b) after Batchelor \& Bowden (1985) shows that the Arkasani Granophyre samples plot in the syn-collisional to post-orogenic granite field.

In summary, field, petrographic and geochemical characteristics of the Arkasani Granophyre indicate that the parent magma was derived by low degrees of partial melting of upper crustal material and was emplaced along the Singhbhum Shear Zone during a late phase of an orogenic movement.

\section{Dalma volcanic rocks}

The Dalma volcanic suite and intercalated sediments constitute the Dalma Belt which forms an east-west range along the middle of the NSMB. The belt is composed of interlayered carbonaceous shales, cherts and felsic and mafic volcanic rocks that grade upwards to high-Mg komatiitic flows and pyroclastics. This volcano-sedimentary succession is followed upwards by pillowed low-K, high-Mg tholeiites. The succession is deformed into a synclinal structure, with the lower horizons exposed along the flanks of the east-west range of hills. The felsic vol-canic rocks exposed near the downstream side of the Chandil Dam on the Subarnarekha River (Fig. 6) w e r e 


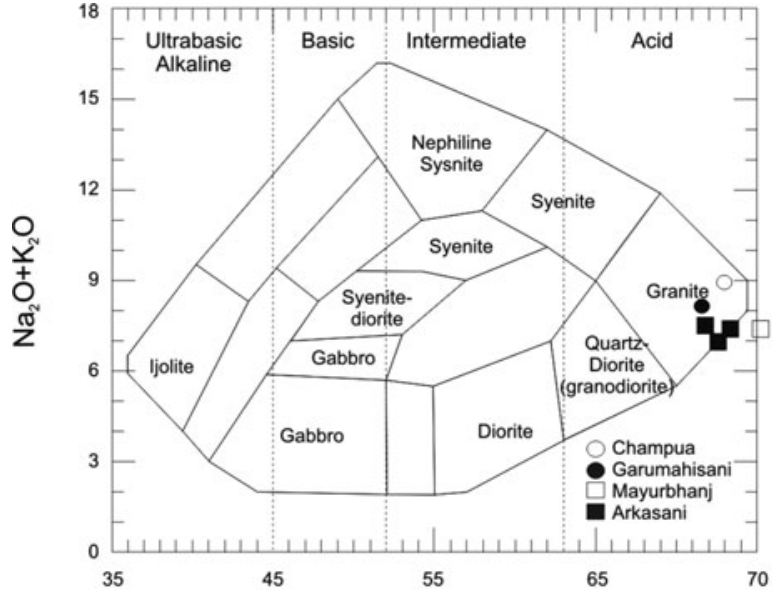

(a)

$\mathrm{SiO}_{2}$

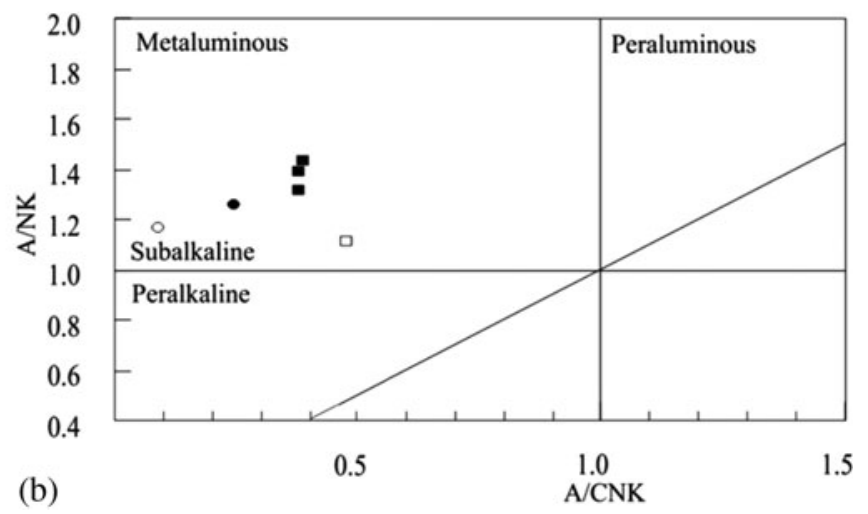

Figure 3. (a) $\mathrm{Na}_{2} \mathrm{O}+\mathrm{K}_{2} \mathrm{O} / \mathrm{SiO}_{2}$ variation plots of Arkasani Granophyre (after Cox et al. 1979), showing the granitic character of the intrusion. (b) Alumina saturation (Shand index) diagram for the studied Arkasani Granophyre (modified after Maniar \& Piccoli, 1989).

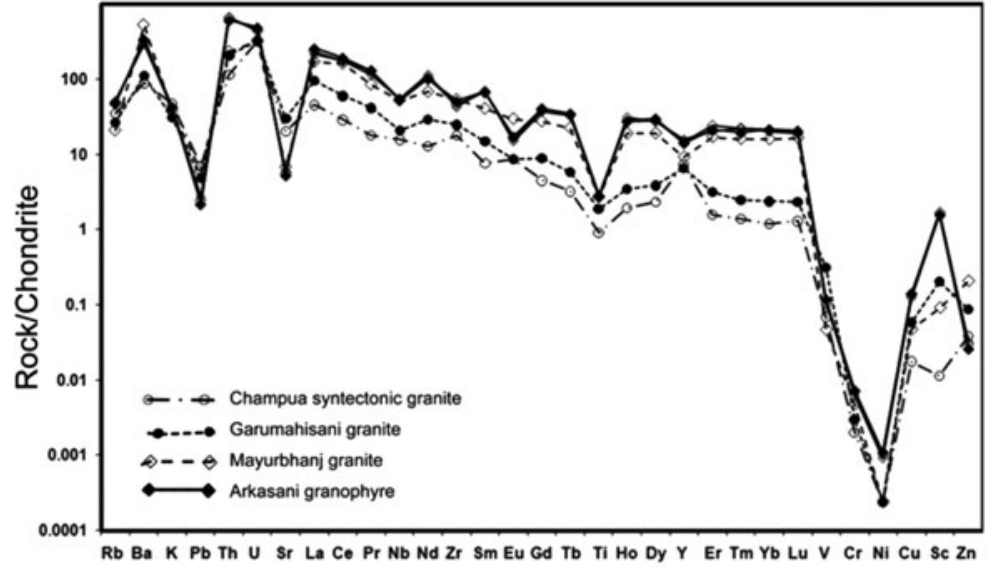

(a)

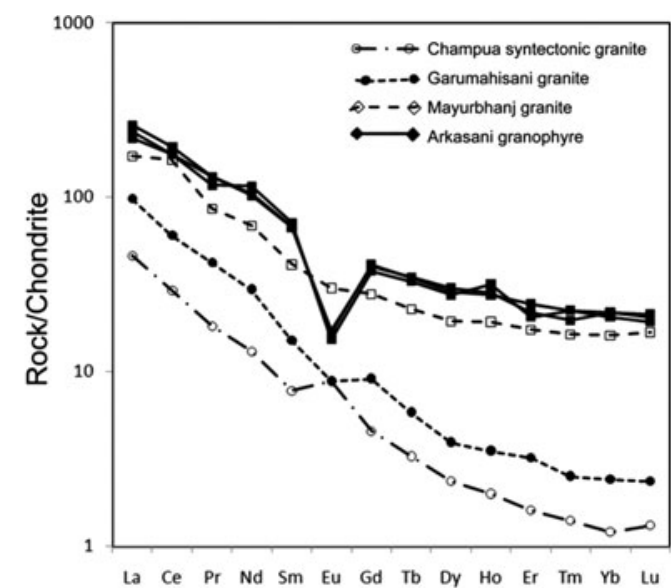

(b)

Figure 4. (a) Trace element spider diagram, normalized by chondrite values of Arkasani Granophyre, after Sun \& McDonough (1989). (b) REE distribution patterns normalized by chondrite values of Arkasani Granophyre, after Boynton (1984).

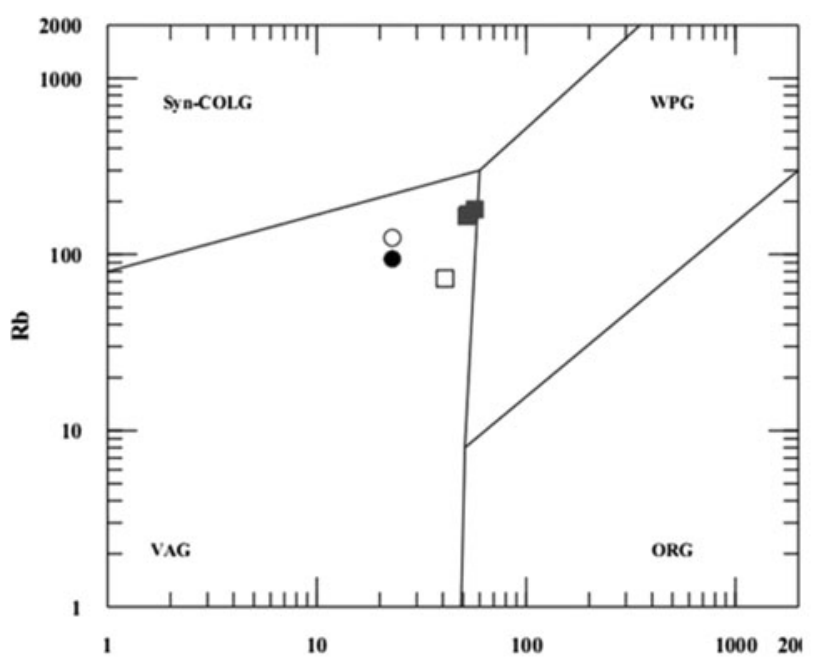

(a)

$\mathrm{Y}+\mathrm{Nb}$

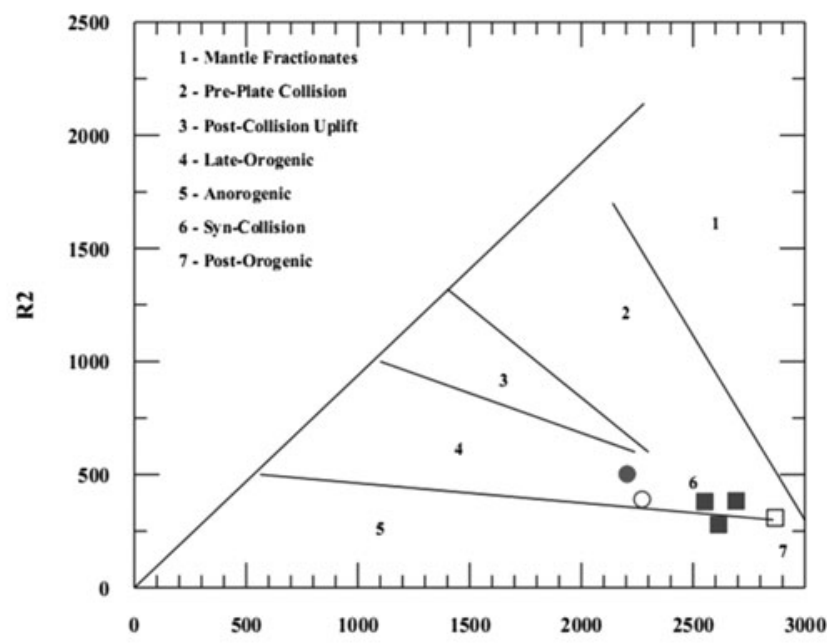

(b)

R1

Figure 5. (a) Geotectonic discrimination diagram after Pearce, Harris \& Tindale (1984). (b) Geotectonic regimes discrimination diagram after Batchelor \& Bowden (1985). $\mathrm{R}_{1}=4 \mathrm{Si}-11(\mathrm{Na}+\mathrm{K})-2(\mathrm{Fe}+\mathrm{Ti}) ; \mathrm{R}_{2}=6 \mathrm{Ca}+2 \mathrm{Mg}+\mathrm{Al}$. Symbols as for Figure 3 . 


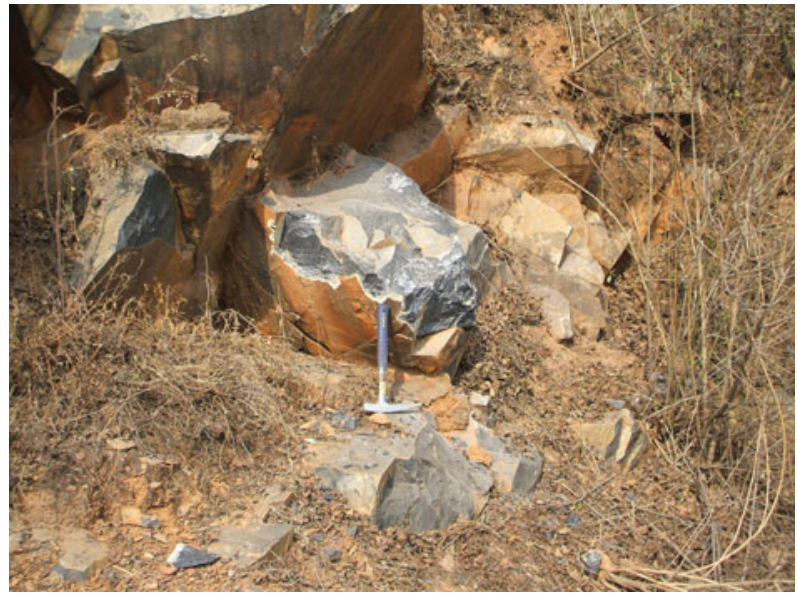

Figure 6. (Colour online) Field photograph of felsic volcanic rocks of Dalma volcanic suite, southern bank of Subarnarekha River, near Chandil dam.

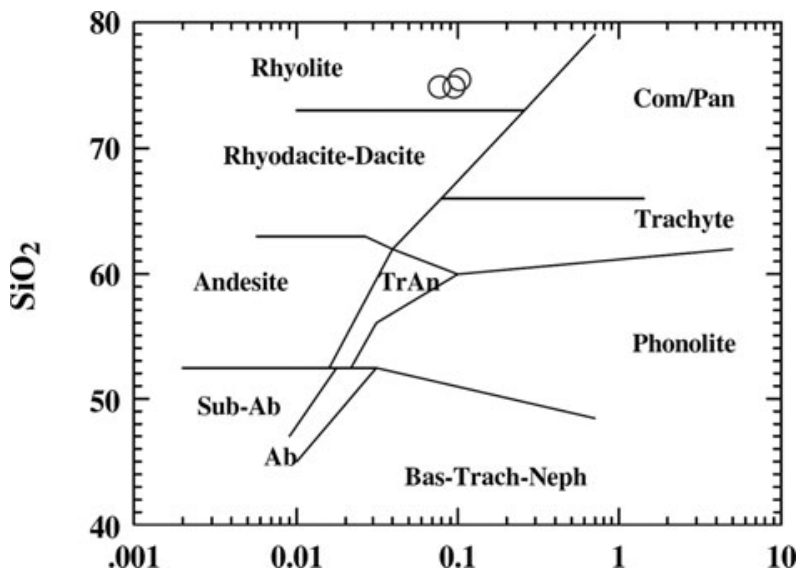

Figure 7. $\mathrm{SiO}_{2}$ v. $\mathrm{Zr} / \mathrm{TiO}_{2} \times 0.0001$ plots of felsic volcanics, Dalma volcanic suite, showing their rhyolitic character (after Winchester \& Floyd 1977).

sampled for geochronological study (see the following section).

Major, trace and REE chemical compositions of the felsic volcanic rocks, obtained at the Wadia Institute of Himalayan Geology by X-ray fluorescence (XRF) and ICP-MS (Khanna et al. 2009), are listed in Table2. The felsic volcanic rocks have high concentrations of $\mathrm{SiO}_{2}$ and $\mathrm{K}_{2} \mathrm{O}+\mathrm{Na}_{2} \mathrm{O}$ and lower abundances of $\mathrm{TiO}_{2}$, $\mathrm{Al}_{2} \mathrm{O}_{3}, \mathrm{MgO}, \mathrm{CaO}$ and $\mathrm{P}_{2} \mathrm{O}_{5}$. The felsic volcanic rocks fall in the rhyolite field of $\mathrm{SiO}_{2} \mathrm{~V} . \mathrm{Zr} / \mathrm{TiO}_{2} \times 0.0001$ classification diagram of Winchester \& Floyd (1977) (Fig. 7). In general, the felsic volcanic rocks display the typical geochemical characteristic of A-type granitoids with high $\mathrm{SiO}_{2}, \mathrm{~N} \mathrm{a}{ }_{2} \mathrm{O}+\mathrm{K}_{2} \mathrm{O}, \mathrm{Fe}_{2} \mathrm{O}_{3}, \mathrm{MgO}$, $\mathrm{Ga} / \mathrm{Al}, \mathrm{Zr}, \mathrm{Nb}, \mathrm{Ga}, \mathrm{Y}$ and REE (except $\mathrm{Eu}$ ), and low $\mathrm{CaO}$ and $\mathrm{Sr}$ (Eby, 1990; Bonin, 2007). A chondritenormalized trace element plot (Fig. 8a) shows enrichment in $\mathrm{Ba}, \mathrm{Th}, \mathrm{U}, \mathrm{Nb}$ and $\mathrm{Zr}$ and depletion in $\mathrm{Pb}, \mathrm{Sr}, \mathrm{Co}$ and Ni. Chondrite-normalized REE patterns of the felsic vol-canic rocks (Fig. 8b) show large negative $\mathrm{Eu}$ anomalies $\left(\mathrm{Eu} / \mathrm{Eu}^{*}=0.43-0.47\right)$ and fractionated and enriched LREE over HREE. Rb/Sr (2.44-2.90), low Sr/Ba, low
$\mathrm{Sr}$ and large Eu anomalies suggest early separation of plagioclase or retention of these elements in feldspar at the source during partial melting (Rollinson, 1993), whereas low contents of $\mathrm{Zr}, \mathrm{P}_{2} \mathrm{O}_{5}, \mathrm{TiO}_{2}$ and $\mathrm{V}$ supports early crystallization and separation of rutile, apatite, zircon and magnetite from the melt. The felsic vol-canic rocks also plot in the within-plate tectonic setting field in $\mathrm{Nb}$ v. Y tectonic discrimination diagram (after Pearce, Harris \& Tindale, 1984; Fig. 9).

The A-type granitoid chemistry of the felsic volcanic rocks lends support to a non-orogenic rift setting (Bar-barin, 1990). Further, their overall geochemical signa-tures favour their generation by low degrees of crustal melting in an extensional tectonic setting under the in-fluence of advecting mafic-ultramafic magma (also see Roy et al. 2002; Sarkar \& Gupta, 2012).

\section{Geochronology}

Sample SC07/5 was taken from the Arkasani Granophyre for geochronology from a $1 \mathrm{~m}$ diameter boulder located c. $20 \mathrm{~m}$ up on the SE side of the forested slopes of Arkasani Hill, on the track to the Arkasani Temple (sampling site coordinates $22^{\circ} 46^{\prime} 11^{\prime}$ ' $\mathrm{N}$, $85^{\circ} 51^{\prime} 20^{\prime}$ ' E). Dark grey to black, unfoliated felsic volcanic rocks occur at the base of the Dalma volcanic succession. Sample SC06/3 was taken from a steep rocky outcrop (Fig. 6) on the left side of the access road to the Subernarekha River road bridge crossing, $250 \mathrm{~m}$ SSE (downstream) of the Chandil Dam wall (22 $58^{\prime} 11.5^{\text {“ }} \mathrm{N} ; 86^{\circ} 01^{\prime} 16.0$ '” E). The felsic volcanic rocks at this site are homogeneous and aphanitic and contain rare, $1 \mathrm{~mm}$ thick, whitish quartz veins (not included in the sample processed). The sample is microfelsitic (in places, spherulitic) to vitrophyric and contains subhedral to anhedral phenocrysts of quartz and sodic plagioclase with accessory biotite, partly replaced by iron oxides, zircon, titanite and tourmaline. The phenocrysts are set in a cryptocrystalline groundmass, at places glassy with variable degree of devitrification. No evidence of flow layering is evident in thin-section.

Crushing and screening of samples was undertaken at Presidency University, Kolkata. Heavy minerals were isolated from $0.5 \mathrm{~kg}$ of sample using conventional heavy-liquid and magnetic techniques. Representative zircons were hand picked, mounted in epoxy and sec-tioned approximately in half, and the mount surface was then polished to expose the grain interiors. $\mathrm{U}, \mathrm{Th}$ and $\mathrm{Pb}$ isotopic measurements were taken using the Perth Consortium SHRIMP II instrument employing operat-ing and data processing procedures similar to those described by Compston, Williams \& Meyer (1984) and Williams et al. (1984). $\mathrm{Pb} / \mathrm{U}$ ratios were determ-ined relative to that of the zircon standards CZ3 and Temora, which have been assigned ${ }^{206} \mathrm{~Pb} /{ }^{238} \mathrm{U}$ values of 0.0914 and 0.066783 corresponding to ${ }^{206} \mathrm{~Pb} /{ }^{238} \mathrm{U}$ dates of 564 Ma and $417 \mathrm{Ma}$, respectively. Data pro-cessing and plot generation were undertaken using the 


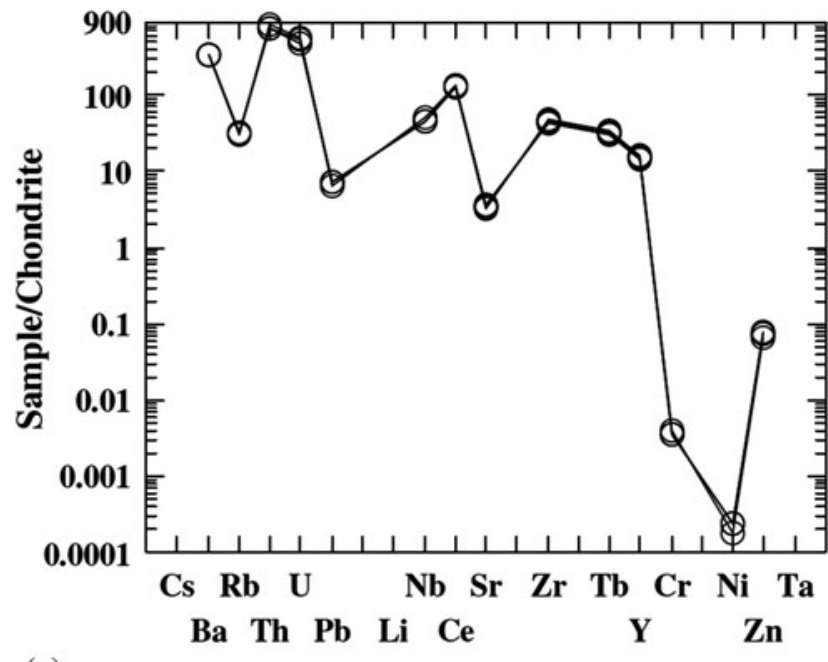

(a)

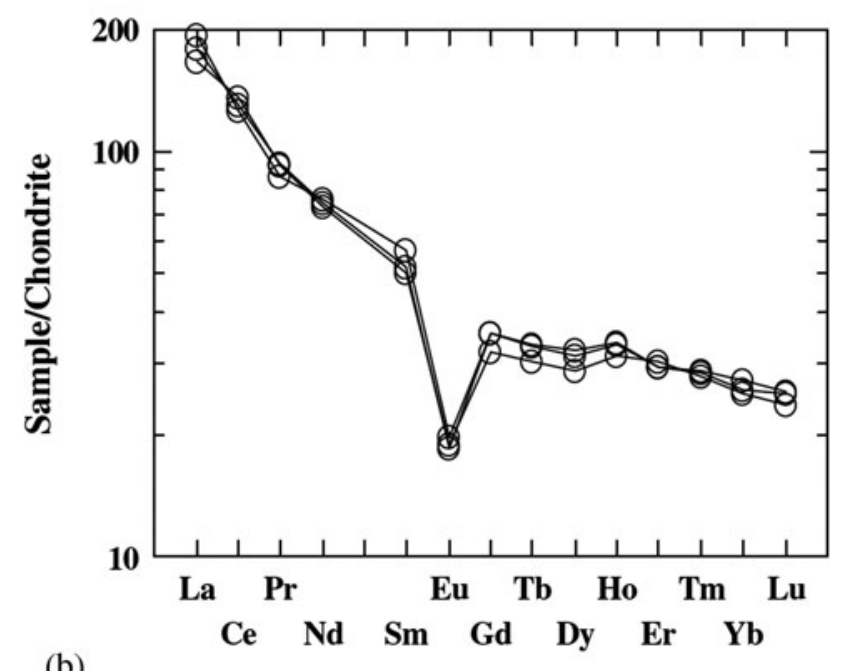

Figure 8. (a) Trace element spider diagram, normalized by chondrite values of the studied felsic volcanic rocks, after Sun \&McDonough (1989). (b) REE distribution patterns normalized by chondrite values of the studied felsic volcanics, after Boynton (1984).

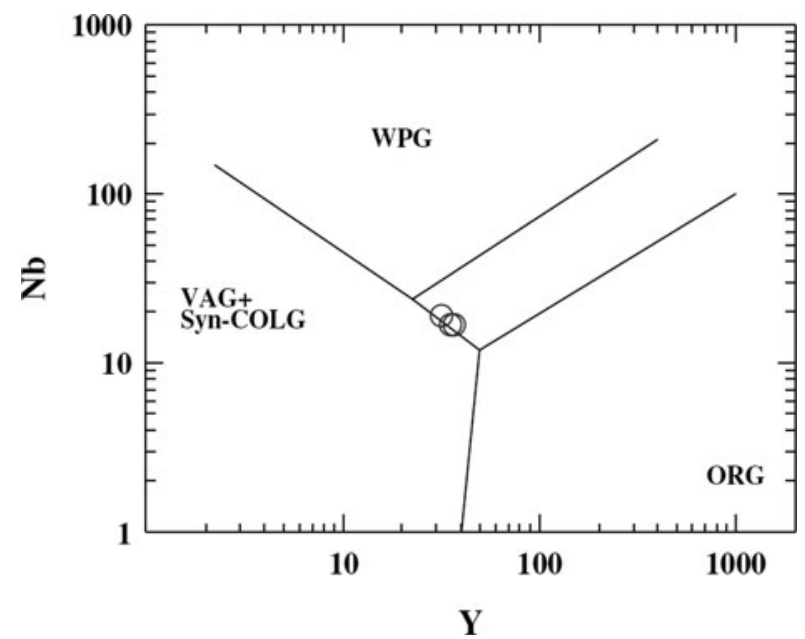

Figure 9. Log Nb v. Log Y plots of Dalma felsic volcanic rocks, after Pearce, Harris \& Tindale (1984). Syn-Colg - syn-collision granite; VAG - volcanic arc granite; WPG - within-plate granite; $\mathrm{ORG}$ - ocean ridge granite.

generalized ion-microprobe data processing software package CONCH (Nelson, 2006).

For the Arkasani Granophyre (sample SC07/05), 21 analyses were obtained of 21 zircons (Table 3; Fig. 10a). Most analyses are concordant within uncertainty, although two analyses indicating high common$\mathrm{Pb}$ contents (12.1 and 16.1) plot along a zero-age discordia line. The population weighted mean ${ }^{207} \mathrm{~Pb} / 206 \mathrm{~Pb}$ ratio and uncertainty correspond to a date of $1861 \pm 8 \mathrm{Ma}$ (chi squared $=0.83$ ). This is interpreted as corresponding to the time of igneous crystalliza-tion of the granophyre. As the Arkasani Granophyre occurs as massive pods and lenses within and aligned along the Singhbhum Shear Zone, and these lenses are only weakly deformed around their margins, the date of $1861 \pm 8 \mathrm{Ma}$ is interpreted as providing the time of the final stages of major tectonic displacement along the Singhbhum Shear Zone.
All 20 analyses obtained for zircons from the felsic volcanic rocks from the base of the Chandil Formation (SC06/03) are concordant within uncertainty (Table 4; Fig. 10b). The population weighted mean ${ }^{207} \mathrm{~Pb} /{ }^{206} \mathrm{~Pb}$ ratio and uncertainty correspond to a date of $1631 \pm 6 \mathrm{Ma}$ (chi squared $=0.71$ ). This is interpreted as corresponding to the time of igneous crystallization of the felsic volcanic rocks and the timing of initiation of volcanism in the Dalma sub-basin.

\section{Discussion}

It has been established that NSMB is a collage of sedimentary and volcano-sedimentary successions that were developed in fault-controlled sub-basins in a regional rift basin that was closed during the Northern Singhbhum Orogeny (Bhattacharya \& Mahapatra, 2008; Sarkar \& Gupta, 2012). The Dhanjori, Chaibasa and Dhalbhum formations, along with the Dalma volcanic and North Dalma volcano-sedimentary successions, have been juxtaposed as curved linear belts within the NSMB. The contacts of these sub-basin ensembles are tectonized (see Saha, 1994; Bhattacharya \& Mahapatra, 2008; Sarkar \& Gupta, 2012) and the times of opening and closure of these sub-basins are not yet firmly established. The Singhbhum Shear Zone separates the Chaibasa Formation from the Dhanjori Formation and movement along the shear zone may also have resulted in the closure of the Dhanjori and Chaibasa sub-basins. The history of sedimentation (Bhattacharya \& Mahapatra, 2008), deformation (Sengupta \& Ghose, 1997) and metamorphism (Mahato et al. 2008) indicates development of this shear zone over a prolonged period of time that must have begun long before the intrusion date of $1861 \pm 8 \mathrm{M} \mathrm{a} \mathrm{o} \mathrm{f} \mathrm{th} \mathrm{e}$ Arkasani Granophyre.

The Arkasani Granophyre evolved through fractional crystallization of a metaluminous felsic magma generated at shallow crustal level and emplaced as 


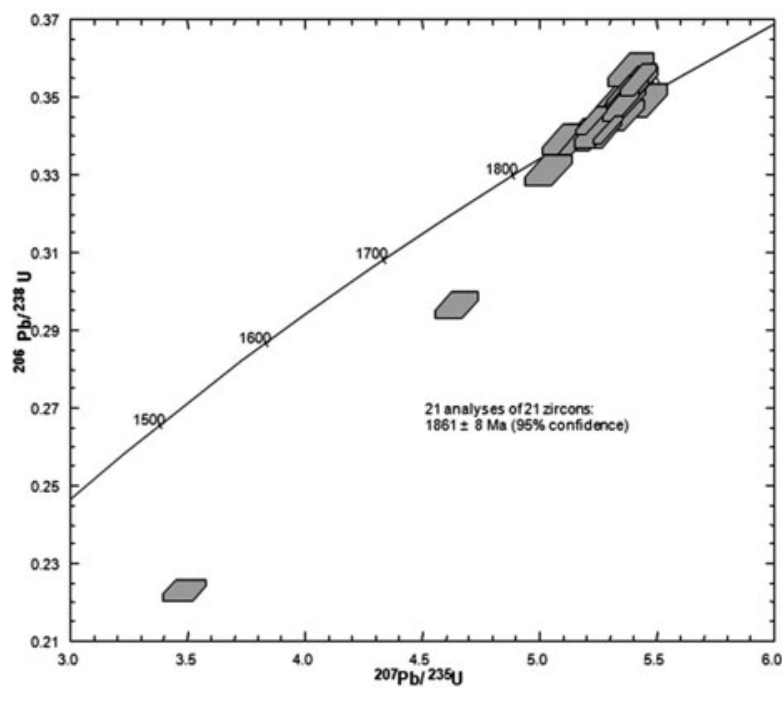

(a)

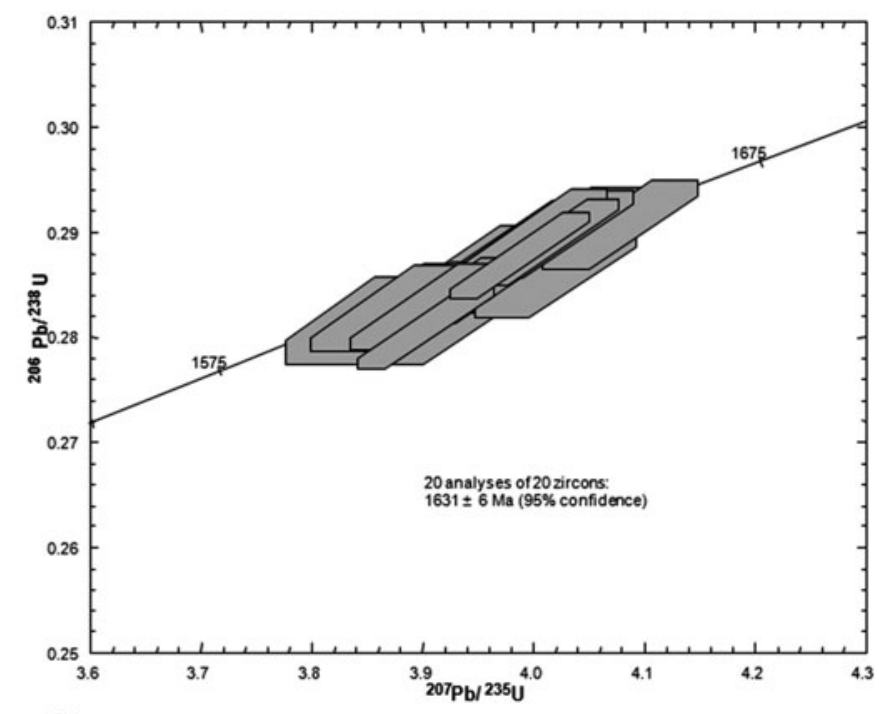

(b)

Figure 10. (a) Wetherill Concordia diagram for sample SC07/05: Arkasani Granophyre. (b) Wetherill Concordia diagram for sample SC06/03: felsic volcanic rocks, Dalma volcanic suite.

numerous isolated bodies aligned along the Singhbhum Shear Zone. Development of schistosity in the Arkasani Granophyre, particularly along the intrusion margins, and the geochemical character of Arkasani Granophyre indicates its syn- to post-kinematic emplacement. The SHRIMP U-Pb zircon date of $1861 \pm 6 \mathrm{Ma}$ for the Arkasani Granophyre therefore provides a minimum age for the shearing/thrusting along the Singhbhum Shear Zone and for the time of closure of the Chaibasa and Dhanjori sub-basins.

Singhbhum Shear Zone hosts minable $\mathrm{Cu}-\mathrm{P}$ and $\mathrm{U}$ mineralizations. $\mathrm{Cu}-\mathrm{P}$ and $\mathrm{U}$ mineralization occurrences are genetically unrelated and $\mathrm{U}$ mineralization might have been superimposed on $\mathrm{Cu}-\mathrm{P}$ mineralization (Sarkar \& Gupta, 2012). The $1.882 \pm 23 \mathrm{Ma}$ uraninite and $1.885 \pm 31 \mathrm{Ma}$ monazite dates (U-Pb dates by ICP-MS laser ablation) reported by Pal et al. (2011) and the date of $1861 \pm 6$ Ma reported here for the Arkasani Granophyre do not support any genetic linkage between granophyre emplacement and ore mineralization. Arkasani Granophyre emplacement might have been preceded by $\mathrm{Cu}-\mathrm{P}$ and $\mathrm{U}$ mineralizations.

The SHRIMP U-Pb zircon date of $1631 \pm 6 \mathrm{Ma}$ obtained for the felsic volcanic rocks of the Dalma subbasin in the north of the Chaibasa sub-basin corresponds to a younger basin formation event that postdates the orogenic movement responsible for closure of the Chaibasa and Dhanjori sub-basins.

The new age data indicate that the evolution of adjacent sub-basins within the NSMB is complex, occurring at different times and by unrelated orogenic movements. Further, it seems evident that the younger subbasins formed further north away from the Archaean basement, and that the accretion of these basin ensembles onto Archaean basement was episodic. Domal exhumation of the Archean granitoid basement due to episodic emplacement of granite sheets during 3.43.0 Ga may have resulted in development of peripheral curved fault systems and down-sagging of banded-ironformation (BIF) -bearing IOG basins (Roy \& Bhattacharya, 2012). Movements along such Archean shear planes might have been responsible for the formation of Proterozoic basins skirting the Archean craton (see Roy and Bhattacharya, 2012). The Dhanjori and Chaibasa subbasins to the north of the Archean basement may be manifestations of such a process. The curved outcrop pattern of these two sub-basins is consistent with their development by the reactivation of ancient (Archean) curved fault systems. Closure and accretion of these two sub-basins on the Archean basement complex took place around $1861 \pm 6 \mathrm{Ma}$, as indicated by the age of emplacement of syn- to post-kinematic emplacement of Arkasani Granophyre. The SSZ, presently defining the contact between Chaibasa and Dhanjori sub-basins, might be related to ancient fault systems that were reactivated during closure of the two sub-basins. The mafic-felsic Dalma volcanic sequence and associated sedi-ments developed in an extensional basin that formed at least 200 Ma after the closure of the Dhanjori-Chaibasa sub-basin and its accretion onto the Archean basement complex. An evolution model for the NSMB is sum-marized in Figure 11.

The results obtained in the present study suggest that the different sub-basins in the NSMB did not evolve simultaneously within a regional rift system, as conceived in earlier models. Instead, the formation and closure of these basins took place diachronously. Late orogenic movement was responsible for juxtaposition of the sub-basins to form the NSMB. The present model also explains the curved pattern of the orogenic belt and the distinctly different petrotectonic evolutionary his-tories of the sub-basins.

Acknowledgements. We are grateful to Dr Subhasis Sengupta, Dr Saumitra Misra and Dr Nilanjan Dasgupta for their help during the different phases of fieldwork. We also thank 


\section{Stage 1}

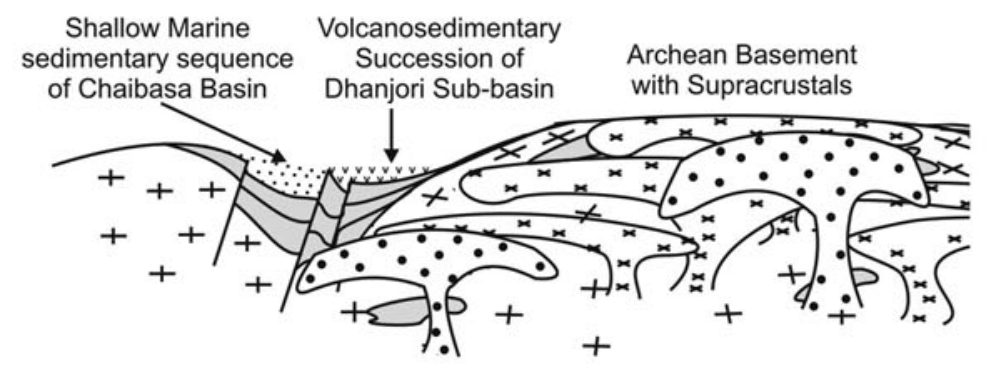

3.4-3.0 Ga Gneisses \& Granite
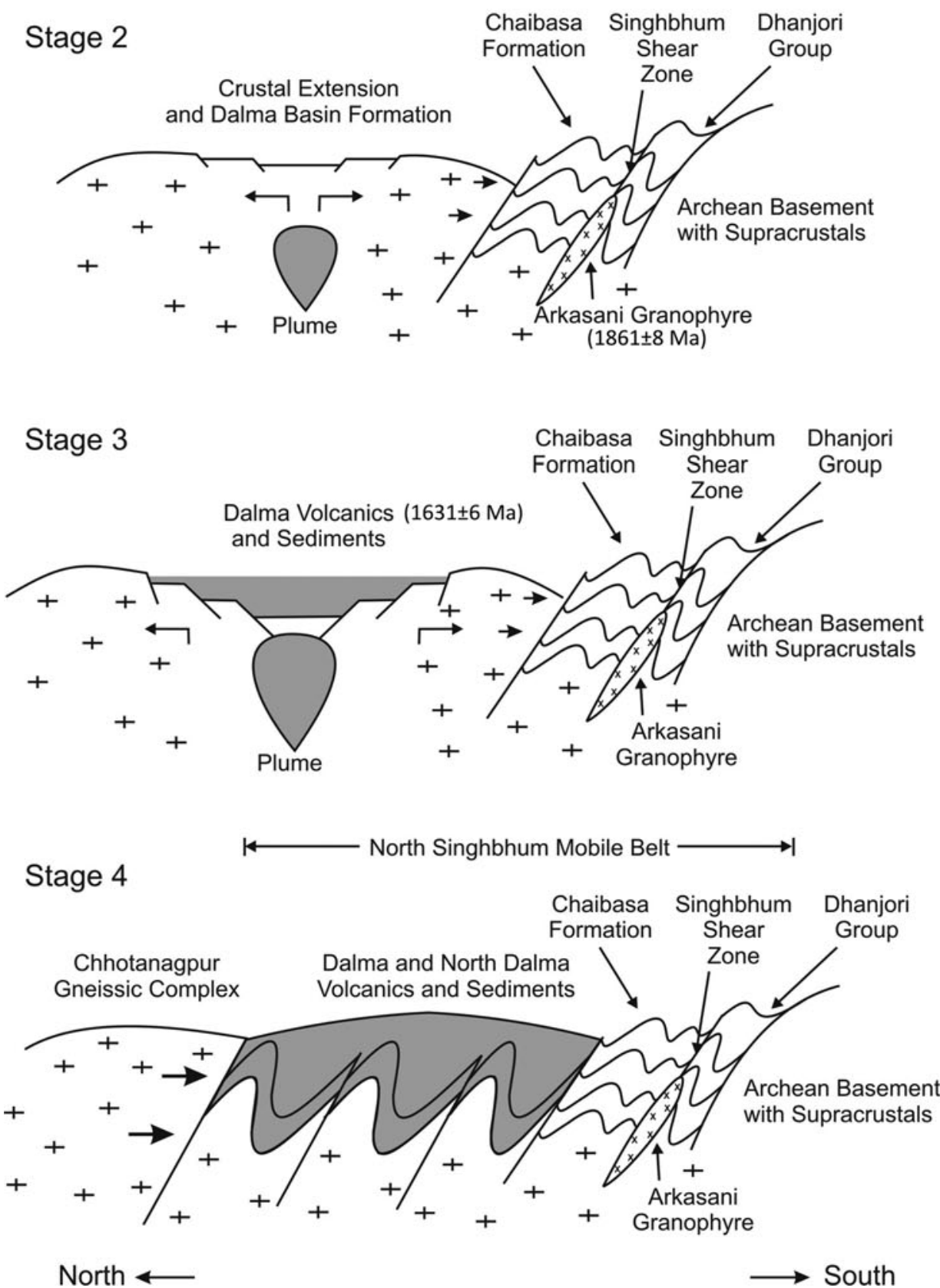

Figure 11. The evolution of the NSMB. (a) During stage 1 (late Archean - early Proterozoic), Dhanjori and Chaibasa sub-basins were formed as a result of reactivation of the early fault system developed skirting the central Archean block due to granite emplacement and doming. (b) During stage 2 (c. $1861 \mathrm{Ma}$ ), the Dhanjori and Chaibasa sub-basins were collapsed and accreted on the southern Archean block with the development of the Singhbhum Shear Zone and emplacement of the Arkasani Granophyre along the shear zone. Development of a zone of crustal extension in the north, under the influence of an uprising plume (see Roy et al. 2002), led to the compression which caused the collapse of the Dhanjori and Chaibasa sub-basins. (c) During stage 3 (c. $1631 \mathrm{Ma}$ ), the Dalma volcanic suite and the associated sediments were deposited in the extensional rift basin after the plume burst. (d)The ensembles of the Dalma sub-basin were juxtaposed on the Dhanjori and Chaibasa sub-basinal rocks after a later terminal orogeny during stage 4 . 
Table 3. Ion microprobe analytical results for sample SC07/5: Arkasani Granophyre.

\begin{tabular}{|c|c|c|c|c|c|c|c|c|c|c|c|c|c|c|c|}
\hline Grain .spot & $U(p p m)$ & Th (ppm) & $P b(p p m)$ & $f 206 \%$ & $207 \mathrm{~Pb} / 206 \mathrm{~Pb}$ & $\pm 1 \sigma$ & $208 \mathrm{~Pb} / 206 \mathrm{~Pb}$ & $\pm 1 \sigma$ & $206 \mathrm{~Pb} / 238 \mathrm{U}$ & $\pm 1 \sigma$ & $207 \mathrm{~Pb} / 235 \mathrm{U}$ & $\pm 1 \sigma$ & $\%$ concordance & $207 \mathrm{~Pb} / 206 \mathrm{~Pb}$ age & $\pm 1 \sigma$ \\
\hline 1.1 & 92 & 42 & 33 & 0.026 & 0.11396 & 0.00117 & 0.12950 & 0.00216 & 0.3331 & 0.0039 & 5.234 & 0.087 & 99 & 1863 & 19 \\
\hline 2.1 & 139 & 64 & 51 & 0.000 & 0.11383 & 0.00087 & 0.12631 & 0.00151 & 0.3454 & 0.0039 & 5.421 & 0.078 & 103 & 1861 & 14 \\
\hline 3.1 & 445 & 290 & 166 & -0.032 & 0.11517 & 0.00057 & 0.18404 & 0.00123 & 0.3334 & 0.0035 & 5.295 & 0.064 & 99 & 1883 & \\
\hline 4.1 & 86 & 46 & 31 & 0.116 & 0.11295 & 0.00161 & 0.15697 & 0.00346 & 0.3235 & 0.0038 & 5.039 & 0.099 & 98 & 1847 & 26 \\
\hline 5.1 & 144 & 77 & 52 & 0.011 & 0.11154 & 0.00097 & 0.15010 & 0.00192 & 0.3311 & 0.0037 & 5.092 & 0.076 & 101 & 1825 & \\
\hline 6.1 & 133 & 69 & 50 & 0.139 & 0.11392 & 0.00124 & 0.14578 & 0.00257 & 0.3447 & 0.0039 & 5.415 & 0.090 & 103 & 1863 & 0 \\
\hline 7.1 & 121 & 65 & 45 & -0.026 & 0.11386 & 0.00122 & 0.15390 & 0.00254 & 0.3424 & 0.0039 & 5.375 & 0.089 & 102 & 1862 & 19 \\
\hline 8.1 & 123 & 76 & 46 & 0.256 & 0.11431 & 0.00163 & 0.16943 & 0.00362 & 0.3329 & 0.0038 & 5.247 & 0.101 & 99 & 1869 & 6 \\
\hline 9.1 & 161 & 113 & 61 & -0.092 & 0.11427 & 0.00096 & 0.19480 & 0.00212 & 0.3392 & 0.0037 & 5.345 & 0.078 & 101 & 1868 & 15 \\
\hline 10.1 & 269 & 126 & 97 & 0.000 & 0.11288 & 0.00064 & 0.13306 & 0.00114 & 0.3354 & 0.0036 & 5.221 & 0.066 & 101 & 1846 & 促 \\
\hline 11.1 & 97 & 46 & 36 & 0.112 & 0.11494 & 0.00266 & 0.12904 & 0.00590 & 0.3405 & 0.0040 & 5.396 & 0.147 & 101 & 1879 & 42 \\
\hline 12.1 & 210 & 158 & 72 & 1.050 & 0.11579 & 0.00177 & 0.20126 & 0.00404 & 0.2910 & 0.0031 & 4.646 & 0.092 & 87 & 1892 & \\
\hline 13.1 & 92 & 40 & 33 & -0.043 & 0.11373 & 0.00155 & 0.12161 & 0.00315 & 0.3406 & 0.0040 & 5.341 & 0.101 & 102 & 1860 & 25 \\
\hline 14.1 & 111 & 61 & 40 & 0.173 & 0.11244 & 0.00144 & 0.14959 & 0.00306 & 0.3309 & 0.0038 & 5.131 & 0.093 & 100 & 1839 & 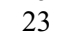 \\
\hline 15.1 & 114 & 54 & 43 & 0.225 & 0.11234 & 0.00140 & 0.14709 & 0.00299 & 0.3479 & 0.0039 & 5.389 & 0.096 & 105 & 1838 & 23 \\
\hline 16.1 & 129 & 130 & 32 & 1.142 & 0.11379 & 0.00245 & 0.15486 & 0.00546 & 0.2224 & 0.0025 & 3.490 & 0.089 & 70 & 1861 & \\
\hline 17.1 & 139 & 75 & 51 & -0.074 & 0.11387 & 0.00133 & 0.15216 & 0.00286 & 0.3349 & 0.0037 & 5.258 & 0.090 & 100 & 1862 & \\
\hline 18.1 & 140 & 47 & 50 & -0.017 & 0.11411 & 0.00100 & 0.09533 & 0.00173 & 0.3420 & 0.0038 & 5.381 & 0.081 & 102 & 1866 & \\
\hline 19.1 & 124 & 69 & 46 & 0.160 & 0.11499 & 0.00166 & 0.15448 & 0.00364 & 0.3369 & 0.0038 & 5.342 & 0.104 & 100 & 1880 & \\
\hline 20.1 & 127 & 74 & 48 & 0.091 & 0.11416 & 0.00140 & 0.15944 & 0.00304 & 0.3404 & 0.0038 & 5.358 & 0.095 & 101 & 1867 & \\
\hline 21.1 & 93 & 43 & 33 & 0.218 & 0.11340 & 0.00156 & 0.12420 & 0.00320 & 0.3324 & 0.0038 & 5.197 & 0.099 & 100 & 1855 & 5 \\
\hline
\end{tabular}

Table 4. Ion microprobe analytical results for sample SC06/3: felsic volcanic rocks of Dalma volcanic suite

\begin{tabular}{|c|c|c|c|c|c|c|c|c|c|c|c|c|c|c|c|}
\hline Grain .spot & $U(p p m)$ & Th (ppm) & $P b(p p m)$ & $f 206 \%$ & $207 \mathrm{~Pb} / 206 \mathrm{~Pb}$ & $\pm 1 \sigma$ & $208 \mathrm{~Pb} / 206 \mathrm{~Pb}$ & $\pm 1 \sigma$ & $206 \mathrm{~Pb} / 238 \mathrm{U}$ & $\pm 1 \sigma$ & $207 \mathrm{~Pb} / 235 \mathrm{U}$ & $\pm 1 \sigma$ & $\%$ concordance & $207 \mathrm{~Pb} / 206 \mathrm{~Pb}$ age & $\pm 1 \sigma$ \\
\hline 1.1 & 420 & 145 & 125 & 0.056 & 0.10047 & 0.00047 & 0.09837 & 0.00071 & 0.2878 & 0.0041 & 3.987 & 0.062 & 100 & 1633 & 9 \\
\hline 2.1 & 152 & 82 & 47 & 0.092 & 0.10039 & 0.00092 & 0.15092 & 0.00178 & 0.2854 & 0.0042 & 3.951 & 0.072 & 99 & 1631 & 17 \\
\hline 3.1 & 454 & 204 & 135 & 0.095 & 0.10072 & 0.00051 & 0.12628 & 0.00091 & 0.2810 & 0.0040 & 3.902 & 0.062 & 97 & 1638 & 9 \\
\hline 4.1 & 197 & 175 & 65 & 0.086 & 0.09983 & 0.00072 & 0.25255 & 0.00165 & 0.2831 & 0.0041 & 3.896 & 0.066 & 99 & 1621 & 13 \\
\hline 5.1 & 241 & 100 & 73 & -0.041 & 0.10068 & 0.00063 & 0.11773 & 0.00100 & 0.2898 & 0.0042 & 4.023 & 0.066 & 100 & 1637 & 12 \\
\hline 6.1 & 218 & 110 & 68 & -0.032 & 0.10098 & 0.00113 & 0.14500 & 0.00240 & 0.2900 & 0.0042 & 4.038 & 0.078 & 100 & 1642 & 21 \\
\hline 7.1 & 138 & 93 & 44 & 0.053 & 0.10194 & 0.00089 & 0.19149 & 0.00178 & 0.2860 & 0.0042 & 4.020 & 0.072 & 98 & 1660 & 16 \\
\hline 8.1 & 112 & 72 & 35 & 0.081 & 0.09993 & 0.00204 & 0.18122 & 0.00457 & 0.2816 & 0.0042 & 3.880 & 0.104 & 99 & 1623 & 38 \\
\hline 9.1 & 278 & 147 & 87 & 0.110 & 0.10010 & 0.00062 & 0.14995 & 0.00115 & 0.2899 & 0.0042 & 4.002 & 0.066 & 101 & 1626 & 12 \\
\hline 10.1 & 207 & 145 & 66 & -0.041 & 0.10038 & 0.00134 & 0.20247 & 0.00301 & 0.2865 & 0.0042 & 3.966 & 0.083 & 100 & 1631 & 25 \\
\hline 11.1 & 168 & 96 & 52 & 0.005 & 0.10052 & 0.00074 & 0.16514 & 0.00135 & 0.2876 & 0.0042 & 3.986 & 0.068 & 100 & 1634 & 14 \\
\hline 12.1 & 244 & 160 & 77 & 0.040 & 0.10022 & 0.00065 & 0.18797 & 0.00130 & 0.2857 & 0.0041 & 3.948 & 0.066 & 100 & 1628 & 12 \\
\hline 13.1 & 358 & 156 & 107 & 0.024 & 0.09987 & 0.00052 & 0.12489 & 0.00087 & 0.2830 & 0.0041 & 3.897 & 0.062 & 99 & 1622 & 10 \\
\hline 14.1 & 192 & 70 & 58 & 0.080 & 0.10016 & 0.00079 & 0.10268 & 0.00135 & 0.2889 & 0.0042 & 3.990 & 0.069 & 101 & 1627 & 15 \\
\hline 15.1 & 191 & 147 & 62 & 0.236 & 0.09944 & 0.00086 & 0.21215 & 0.00187 & 0.2829 & 0.0041 & 3.879 & 0.069 & 100 & 1614 & \\
\hline 16.1 & 291 & 143 & 90 & 0.020 & 0.10067 & 0.00054 & 0.14117 & 0.00089 & 0.2891 & 0.0042 & 4.013 & 0.064 & 100 & 1636 & 10 \\
\hline 17.1 & 194 & 99 & 60 & 0.049 & 0.10022 & 0.00070 & 0.14410 & 0.00122 & 0.2871 & 0.0042 & 3.967 & 0.067 & 100 & 1628 & 13 \\
\hline 18.1 & 143 & 112 & 48 & 0.020 & 0.10175 & 0.00077 & 0.22597 & 0.00165 & 0.2907 & 0.0043 & 4.078 & 0.071 & 99 & 1656 & 14 \\
\hline 19.1 & 241 & 148 & 75 & 0.094 & 0.09909 & 0.00071 & 0.17200 & 0.00142 & 0.2828 & 0.0041 & 3.864 & 0.066 & 100 & 1607 & 13 \\
\hline 20.1 & 363 & 202 & 112 & 0.148 & 0.10028 & 0.00059 & 0.15977 & 0.00114 & 0.2835 & 0.0041 & 3.919 & 0.064 & 99 & 1629 & 11 \\
\hline
\end{tabular}


Mr Kaushik Kiran Ghosh, who drafted some of the figures. We wish to acknowledge the technical support provided by Tarak Pradhan at Presidency University. Finally, we extend our sincere gratitude to anonymous reviewers for their constructive suggestions.

\section{References}

BANERJEE, A. K., BHATTACHARYA, N. C. \& ChatTAOPAdHYAY, B. 1978. Arkasani granophyres from the Singhbhum shear zone, Bihar. Journal of the Geological Society of India 19, 350-8.

BARBARIN, B. 1990. Granitoids: main petrogenetic classification in relation to origin and tectonic setting. Geological Journal 25, 227-38.

BATCHELOR, R. A. \& BOWDEN, P. 1985. Petrologic interpretation of granitoid rocks series using multicationic parameters. Chemical Geology 48, 43-55.

BHATTACHARYA, H. N. \& MAHAPATRA, S. 2008. Evolution of the Proterozoic rift margin sediments-North Singhbhum Mobile Belt, Jharkhand-Orissa, India. Precambrian Research 162, 302-16.

BONIN, B. 2007. A-type granites and related rocks: evolution of a concept, problems and prospects. Lithos 97, 1-29.

Bose, M. K. and CHAKRABORTI, M. K. 1981. Fossil marinal basin from the Indian Shield: a model for the evolution of Singhbhum Precambrian belt, Eastern India. Geologische Rundschau 70, 504-18.

Bose, M. K., ChaKrabarti, M. K. \& SAUnders, A. D. 1989. Petrochemistry of the lavas from Proterozoic Dalma volcanic belt, Singhbhum, eastern India. Geologische Rundschau 78, 633-48.

BOYNTON, W. V. 1984. Cosmochemistry of the rare earth elements: meteorite studies. In Rare Earth Element Geochemistry (ed. P. Henderson), pp. 63-114. Elsevier, Amsterdam.

ChatTOPadhyay, B. 1990. The main hill Arkasani granophyres pluton in the Precambrians of eastern India-a model of two stage intrusion. Indian Journal of Geo$\operatorname{logy}$ 62, 233-48.

Clarke, D. B. 1992. Granitoid Rocks. London: Chapman and Hall, $283 \mathrm{pp}$

Compston, W., Williams, I. S. \& Meyer, C. 1984. U$\mathrm{Pb}$ geochronology of zircons from lunar breccia 73217 using a sensitive high mass-resolution ion microprobe. Journal of Geophysical Research 89, B252-B534.

Cox, K. G., Bell, J. D. \& Pankhurst, R. J. 1979. The Interpretation of Igneous Rocks. London: George Allen \& Unwin Press, 450 pp.

DunN, J. A. 1929. The geology of north Singhbhum-Orissa including parts of Ranchi and Manbhum districts. Memoir of the Geological Survey of India 54, 1-166.

DunN, J. A. and DEY, A. K. 1942. Geology and petrology of Eastern Singhbhum and surrounding areas. Memoir of the Geological survey of India 69(2), 281-456.

EBY, G. N. 1990. The A-type granitoids: a review of their occurrence and chemical characteristics and speculations on their petrogenesis. Lithos 26, 115-34.

GUPTA, A. \& BASU, A. 2000. North Singhbhum Proterozoicmobile belt, eastern India: a review. Geological Survey of India, Special Publication no. 55, 195-226.

GuPTA, A., BASU, A. \& GHOSH, P. K. 1980. The Proterozoic ultramafic and mafic lavas and tuffs of the Dalma greenstone belt, Singhbhum, eastern India. Canadian Journal of Earth Science 17, 210-31.

Jung, S., Hoernes, S., MAsberg, P. \& Hoffer, E. 1999. The petrogenesis of some migmatites and granites (Central
Damara Orogen, Namibia): evidence for disequilibrium melting, wall-rock contamination and crystal fractionation. Journal of Petrology 40, 1241-69.

KhanNa, P. P., SAini, N. K., MuKherJee, P. K. \& PuROHIT, K. K. 2009. An appraisal of ICP-MS technique for determination of REEs: long term QC assessment of silicate rock analysis. Himalayan Geology 30, 95-9.

Mahato, S., Goon, S., Bhattacharya, A., Misra, B. \& BERNHARDT, H. J. 2008. Thermal-tectonic evolution of the North Singhbhum Mobile Belt (eastern India): a view from the western part of the belt. Precambrian Research 162, 102-27.

MANIAR, P. D. \& PICCOLI, P. M. 1989. Tectonic discrimination of granitoids. Bulletin of the Geological Society of America 101, 635-43.

MuKHOPADHYAY, D. 1984. The Singhbhum Shear Zone and its place in the evolution of the Precambrian mobile belt of north Singhbhum. Journal of the Indian Society of Earth Science, CEISM Volume, 205-12.

NELSON, D. R. 2006. CONCH: a versatile Visual Basic program for the interactive processing of ion-microprobe data. Computer and Geoscience 32, 1479-98.

Pal, D. C., Chaudhuri, T., McFarlane, C. H., MukherJee, A. \& SARANGI, A. K. 2011. Mineral chemistry and in situ dating of allanite, and geochemistry of its host rocks in the Bagjata Uranium Mine, Singhbhum Shear Zone, India: Implications for the chemical evolution of REE mineralization and mobilization. Economic Geo$\log y$ 106, 1155-71.

Pearce, J. A., Harris, N. B. W. \& Tindale, A. G. 1984 Trace element discrimination diagrams for the tectonic interpretation of granitic rocks. Journal of Petrology $\mathbf{2 5}$, 956-83.

Rollinson, H. R. 1993. Using Geochemical Data: Evolution, Presentation, Interpretation. Hariow: Addsion Wesley Longman, $352 \mathrm{pp}$.

ROY, A. B. \& BHATTACHARYA, H. N. 2012. Tectonostratigraphic and geochronologic reappraisal constraining the growth and evolution of Singhbhum Archaean Craton, eastern India. Journal of the Geological Society of India 80, 455-69.

Roy, A., SARKar, A., Jeyakumar, S., Aggrawal, S. K. \& EBIHARA, M. 2002. Sm-Nd age and mantle source characteristics of the Dhanjori volcanic rocks, Eastern India. Geochemical Journal 36, 503-18.

SAHA, A. K. 1994. Crustal evolution of Singhbhum-North Orissa, eastern India. Geological Society of India, Memoir no. 27, $341 \mathrm{pp}$

SARKAR, A. N. 1982. Precambrian tectonic evolution of eastern India: a model of converging microplates. Tectonophysics 86, 363-97.

SARKAR, S. C. 2000. Crustal evolution and metallogeny in the eastern Indian craton. Geological Survey of India, Special Publication no. 55, 169-94.

SARKAR, S. C. \& GUPTA, A. 2012. Crustal Evolution and Metallogeny in India. Cambridge: Cambridge University Press, $840 \mathrm{pp}$.

SARKAR, S. C., GUPTA, A. \& BASU, A. 1992. North Singhbhum Proterozoic mobile belt, eastern India: its character, evolution and metallogeny. In Metallogeny Related to Tectonics of the Proterozoic Mobile Belts (ed. S.C. Sarkar), pp. 271-305. New Delhi: Oxford and IBH Publishing Co.

SARKAR, S. N. \& SAHA, A. K. 1977. The present status of the Precambrian stratigraphy, tectonics and geochronology of Singhbhum-Keonjhar Mayurbhanj region, Eastern India. Indian Journal of Earth Science, S. Ray Volume, $37-65$. 
SARKAR, S. N. \& SAHA, A. K. 1983. Structure and tectonics of the Singhbhum-Orissa iron ore craton, eastern India. In Structure and Tectonics of Precambrian rocks in India (ed. Roy Sinha), pp. 1-25. Hindusthan Publishing Corporation, New Delhi, Recent Researches in Geology no. 10.

Sengupta, S., Bandyopadhyay, P. K., VAn Den Hul, H. J. \& ChatTopadhyay, B. 1984. Arkasani Granophyre: Proterozoic intraplate acid magmatic activity in the Singhbhum Craton, Eastern India. Neues Jahrbuch für Mineralogie Abhandlung 148, 328-43.

SEnguPTA, S. \& GHOSE, S. K. 1997. The kinematic history of the Singhbhum Shear Zone. Proceedings of the Indian Academy of Science (Earth and Planetary Science) 106, 185-96.
Sun, S. S. \& McDonougH, W. F. 1989. Chemical and isotopic systematic of ocean basalts: implication for mantle composition and processes. In Magmatism in Ocean Basins (eds A. D. Saunders \& M. Norry), pp. 313-45. Geological Society of London, Special Publication no. 42.

Williams, I. S., Compston, W., Black, L. P., IREland, T. R. \& Foster, J. J. 1984. Unsupported radiogenic $\mathrm{Pb}$ in zircon: a case for anomalously high $\mathrm{Pb}-\mathrm{Pb}, \mathrm{U}-\mathrm{Pb}$ and $\mathrm{Th}-\mathrm{Pb}$ ages. Contributions to Mineralogy and Petrology $\mathbf{8 8}, 322-7$.

WinCHESTER, J. A. \& FloYD, P. A. 1977. Geochemical discrimination of different magma series and their differentiation products using immobile elements. Chemical Geology 20, 325-43. 